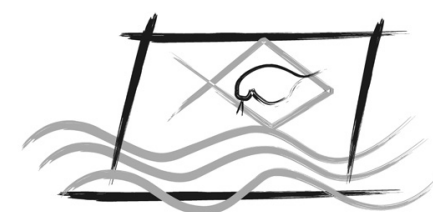

ECOTOX - BRASIL

\title{
Acute toxicity of soil samples under the atmospheric influence of an industrial complex using Swiss mice
}

\author{
F.M.R. DA Silva JÚNIOR ${ }^{1,2}$; E.M. Garcia ${ }^{1,2}$ \& A.L. MucCILlo-Baisch ${ }^{1,2}$ \\ ${ }^{1}$ Laboratório de Ensaios Farmacológicos e Toxicológicos, Instituto de Ciências Biológicas, Universidade Federal \\ do Rio Grande do Sul - FURG, Rio Grande - RS, Brasil. \\ ${ }^{2}$ Programa de Pós graduação em Ciências da Saúde - Hospital Universitário, Universidade Federal \\ do Rio Grande - FURG, Rio Grande - RS, Brasil.
}

(Received September 12, 2013; Accept February 24, 2014)

\begin{abstract}
Some factors may contribute to potentiate the toxicity effects of soil contaminants on the organisms, among them is the acidification process derived from acid rain. Thus, the aim of this study was to assess the toxicity of a soil under the influence of an industrial complex through exposure of Swiss mice to soil leachates in different $\mathrm{pH}$ values. Soil samples were collected in Rio Grande, Brazil. At the laboratory, Swiss male mice were exposed by gavage (single dose) to soil extracts with different $\mathrm{pH}$ values (7.0, 5.2 and 3.6). The results showed toxic effects related to the decrease in $\mathrm{pH}$ and to increase in the concentration of soil extract. Therefore, the results showed that acid rain simulating solutions are able to potentiate the toxicity of the soil contaminants, and these conditions must be taken into account to environmental diagnosis in cities with occurrence of acid rain such as Rio Grande.
\end{abstract}

Keywords: short-term bioassays; soil contamination; rodent.

\section{INTRODUCTION}

Soil differs from other environmental compartments due to there is not a continuous displacement, as in the case of atmospheric circulation and surface water, which may cause an increase in the residence time of the contaminants at the local level. In addition, soil can function as a filter or as a source of contaminants to other compartments requiring thus special care in their use (Da Silva Júnior \& Vargas, 2007).

Some special conditions contribute to the potential toxicity of soils, including acidification. This increased sensitivity is due to increased solubility of the metallic elements in this low $\mathrm{pH}$ condition. However, complex mixtures may reflect this potentiation depending on the concentration of metallic elements, their degree of speciation and environmental conditions, such as the occurrence of acid rain (Pueyo et al., 2003).

The municipality of Rio Grande is located near the estuary of Patos Lagoon. In this estuary, has settled an industrial park with different sectors and industries, due to this park, has already been noted that the city has favorable conditions to the phenomenon of acid rain during most of year (Mirlean et al., 2000, Da Silva Júnior et al., 2013).

Although toxicological studies of drugs have been using rodents to predict damage to human health, these organisms have been little used to measure environmental damage caused by contaminated soils. Studies have been limited to investigate sub-lethal effects such as biochemical (Fouchécourt et al., 1999, Budinsky et al., 2008, Da Silva Júnior et al., 2013), genetic (Alexander et al., 2002) and histological (Garipay et al., 2003) damage. This study aimed to investigate the acute toxicity of different fraction of a soil under the atmospheric influence of an industrial complex using Swiss mice.

\section{MATERIAL AND METHODS}

\section{Soil samples}

Soil samples were collected from one sites in Rio Grande municipality, state of Rio Grande do Sul, southern Brazil, 
located in an urban area which is under the influence of fertilizer plants and a petroleum refinery via atmosphere.

\section{Collection and storage of surface soil}

At each collection site, a simple sampling was done and soil was collected at a depth of $20 \mathrm{~cm}$, using a plastic shovel. Stones and plant material were removed. In the field, the material was placed in plastic bags and transported into the laboratory. In the laboratory, the soil was separated and stored at $-20{ }^{\circ} \mathrm{C}$ to biological assays and room temperature to metal analysis.

\section{Soil extraction}

Soil samples were shaken at room temperature for $24 \mathrm{~h}$ with three different solvents (soil: solvent, 1:2. $\mathrm{g} \mathrm{mL}^{-1}$ ): (i) distilled water, (ii) buffer solution of acetic acid and sodium hydroxide (pH 5.2), and (iii) buffer solution of acetic acid ( $\mathrm{pH}$ 3.6). This acidic solution were prepared to simulate, respectively, the average $\mathrm{pH}$ of rainfall in Rio Grande $(\mathrm{pH}=5.2)$ and the lowest $(\mathrm{pH}=3.6)$ recorded by Mirlean et al. (2000).

\section{Acute toxicity test with mice (Mus musculus)}

In order to evaluate acute toxicity in mice by mortality rate, the solutions of contaminated soil with different $\mathrm{pH}$ values were administered in mice weighing between 35 and $50 \mathrm{~g}$ in four different doses $\left(357,714,1071\right.$, and $1428 \mathrm{mg} \mathrm{kg}^{-1}$ body weight). These concentrations were chosen because they are close to the values of intake in humans geophagy events described by Calabrese et al. (1997). The control of each experiment was done only using solvent. The administration was done orally (gavage) in a single dose. Each treatment consisted of eight animals and signs of lethargy and mortality were monitored for 14 days. State of lethargy was considered when the animal was stimulated by touch and remained motionless, showing no signs of reaction.

\section{Quantification metals in the extracts}

Copper and zinc in soil extract samples were analyzed by flame atomic absorption spectrophotometry (AAS PerkinElmer 800), while electrochemical atomization mode with Zeeman correction was used in chromium, nickel, lead, arsenic and cadmium analysis in soil extractions samples. Maximal value of relative standard deviation for 3 replicate analysis of an individual sample was less than $4 \%$.

\section{RESULTS AND DISCUSSION}

The results of metals quantification in the extracts evaluated are described in Table 1. The concentrations of chromium, nickel and lead exceeded the maximum allowable limits for groundwater according to Brazilian standards (CONAMA, 2009). Considering the acid extracts in addition to $\mathrm{Cr}, \mathrm{Ni}$ and $\mathrm{Pb}$, arsenic also exceeded legal limits. The concentration of some elements such as arsenic, cadmium, copper and zinc in acid extracts increased.

Table 2 shows the mortality associated to three treatments, at different concentrations of contaminated soil. No effect was observed in the conventional treatment (distilled water), whereas in the alternative treatments (simulating the average $\mathrm{pH}$ of rainfall and acid rain in Rio Grande) effects were observed at higher concentrations. In the treatment simulating the average $\mathrm{pH}$ of rainfall, the highest concentration of soil $\left(1428 \mathrm{mg} \mathrm{kg}^{-1}\right)$ resulted in lethargic effects on animals, while the two highest concentrations of soil (1071 and $1428 \mathrm{mg} \mathrm{kg}$ $\left.{ }^{1}\right)$ for the treatment simulating the effects of acid rain caused mortality ( 25 and $37.5 \%$ respectively).

The short-term bioassay with mice has not been applied to assess toxicity of contaminated soils. This assay was proposed to evaluate the toxicity of contaminated soil in three different situations, dissolved in solvents with different $\mathrm{pH}$ conditions: distilled water and two acidic solutions with $\mathrm{pH}$ of 5.2 and 3.6. Although none of the treatments have induced a high mortality rate of animals, the most pronounced results were obtained from treatments of soil dissolved in acid.

These two acid solvents were chosen to simulate leaching events in soil under normal ( $\mathrm{pH}$ 5.2) and acidic ( $\mathrm{pH}$ 3.6) rainfall conditions. These $\mathrm{pH}$ values were taken from Mirlean et al. (2000) for rainfall in Rio Grande. In fact, acidic conditions may increase the bioavailability of toxic compounds such as heavy metals (Pueyo et al., 2003, Da Silva Júnior et al., 2009).

Table 1 - Metal concentration $\left(\mu \mathrm{g} \mathrm{L}^{-1}\right)$ in three inorganic fractions (extraction) of the contaminated urban soil.

\begin{tabular}{|c|c|c|c|c|c|c|c|}
\hline Samples & As & $\mathrm{Cd}$ & $\mathrm{Cr}$ & $\mathrm{Cu}$ & $\mathrm{Ni}$ & $\mathrm{Pb}$ & $\mathrm{Zn}$ \\
\hline $\begin{array}{l}\text { Contaminated } \\
\text { soil (aqueous } \\
\text { fraction) }\end{array}$ & 5.058 & 1.740 & 101.180 & 183.360 & 73.860 & 116.400 & 203.000 \\
\hline $\begin{array}{l}\text { Contaminated } \\
\text { soil ( } \mathrm{pH} 5.2 \\
\text { fraction) }\end{array}$ & 12.510 & 3.404 & 63.300 & 235.600 & 68.520 & 48.200 & 899.400 \\
\hline $\begin{array}{l}\text { Contaminated } \\
\text { soil }(\mathrm{pH} 3.6 \\
\text { fraction) }\end{array}$ & 15.654 & 4.294 & 57.700 & 286.800 & 87.680 & 56.800 & 497.400 \\
\hline $\begin{array}{l}\text { Brazilian } \\
\text { standards to } \\
\text { groundwater }{ }^{1}\end{array}$ & 10 & 5 & 50 & 2000 & 20 & 10 & 1050 \\
\hline
\end{tabular}

Table 2 - Mortality and lethargy of mice exposed by gavage (single dose) at five concentrations of three fractions of contaminated urban soil extracts.

\begin{tabular}{lccc}
\hline $\begin{array}{l}\text { Concentration } \\
\left(\mathrm{mg} \mathrm{kg}^{-1}\right)\end{array}$ & Aqueous fraction & $\mathrm{pH} 5.2$ fraction & $\mathrm{pH} 3.6$ fraction \\
\cline { 2 - 4 } 0 & 0 & 0 & 0 \\
357 & 0 & 0 & 0 \\
714 & 0 & 0 & $0 *$ \\
1071 & 0 & 0 & $25 \% *$ \\
1428 & 0 & $0^{*}$ & $37,5 \% *$ \\
\hline
\end{tabular}


Acidic extract of soil has already shown a greater mutagenic character than aqueous extract of the same soil sample (Da Silva Júnior et al., 2009). The results of this study highlight the risks for human populations and other organisms when exposed to contaminated soil after rain events and acid rain.

The increased toxicity observed in the test with mice was associated with the increased acidity in the fraction extracted of the soil. Among the analyzed elements, arsenic, cadmium, zinc and copper showed clear increase with the decrease in $\mathrm{pH}$ of the extract. So, among the elements analyzed, these elements are candidates as the highest contributors to the toxicity of the studied soil samples.

\section{CONCLUSION}

The use of acute toxicity test in mice was useful for predicting the effect of events of acid rain potentiate the toxicity of soils with moderate level of contamination.

\section{Acknowledgements}

The authors thank to Coordenação de Aperfeiçoamento de Pessoal de Nível Superior, CAPES, for the Doctoral (F.M.R. da Silva Júnior) and Master (E. M. Garcia) scholarships.

\section{REFERENCES}

ALEXANDER R.R.; TANG J. \& ALEXANDER M., 2002. Genotoxicity is Unrelated to Total Concentration of Priority Carcinogenic Polycyclic Aromatic Hydrocarbons in Soils Undergoing Biological Treatment. J. Environ. Qual, 31: 150154. http://dx.doi.org/10.2134/jeq2002.0150

BUDINSKY R.A.; ROWLANDS J.C.; CASTEEL S.; FENT G.; CUSHING C.A.; NEWSTED J.; GIESY J.P.; RUBY M.V. \& AYLWARD L.L., 2008. A pilot study of oral bioavailability of dioxins and furans from contaminated soils: Impact of differential hepatic enzyme activity and species differences. Chemosphere, 70: 1774-1786. http://dx.doi.org/10.1016/j. chemosphere.2007.08.035

CALABRESE E.; STANEK E.; PEKOW P. \& BARNES R., 1997. Soil Ingestion Estimates for Children Residing on a Superfund Site. Ecotox. Environ. Saf., 36: 258-268. http://dx.doi. org/10.1006/eesa.1996.1511
CONAMA (Conselho Nacional do Meio Ambiente). 2009. Norma 420. Dispõe sobre critérios e valores orientadores de qualidade do solo quanto à presença de substâncias químicas e estabelece diretrizes para o gerenciamento ambiental de áreas contaminadas por essas substâncias em decorrência de atividades antrópicas. Brasília, DF.

DA SILVA JÚNIOR F.M.R. \& VARGAS V.M.F., 2007. Avaliação de áreas sob a influência de uma termelétrica a carvão através de ensaio de genotoxicidade. J. Braz. Soc. Ecotox., 2: 197-199.

DA SILVA JÚNIOR F.M.R.; ROCHA J.A.V. \& VARGAS V.M.F., 2009. Extraction parameters in the mutagenicity assay of soil samples. Sci. Total Environ. 407: 6017-6023. http://dx.doi. org/10.1016/j.scitotenv.2009.08.021

DA SILVA JÚNIOR, F.M.R.; SILVA, P. F.; GARCIA, E.M.; KLEIN, R.D.; PERAZA, G.; BAISCH, P.; VARGAS, V.M.F. \& MUCCILLO-BAISCH, A.L, 2013. Toxic effects of the ingestion of water-soluble elements found in soil under the atmospheric influence of an industrial complex. Environ. Geochem. Health, 35: 317-331. http://dx.doi.org/10.1007/s10653-012-9496-5

FOUCHÉCOURT M.O.; ARNOLD M.; BERNY P.; VIDEMANN B.; RETHER B. \& RIVIÈRE J.L., 1999. Assessment of the bioavailability of PAHs in rats exposed to a polluted soil by natural routes: induction of EROD activity and DNA adducts and PAH burden in bothh liver and lung. Environ. Res., 80, p. 330-339. http://dx.doi.org/10.1006/enrs.1998.3932

GARIPAY R.C.; MURO-CACHO C.; KHLIFI A.; HAHN G.; STEDEFORD T.; BANASIK M. \& HARBISON, D., 2003. Tissue metal concentrations and histopathology ofrats gavaged with vitrified soil obtained from the former Charleston Naval Shipyard (SC, USA). J. Hazard. Mat. A, 100: 1-12. http://dx.doi. org/10.1016/S0304-3894(03)00034-7

MIRLEAN, N.; VANZ, A. \& BAISCH, P., 2000. Níveis e origem da acidificação das chuvas na região do Rio Grande. Quim Nova, 23: 590-593. http://dx.doi.org/10.1590/S0100-40422000000500004

PUEYO M.; SASTRE J.; HERNANDEZ E.; VIDAL M.; LOPEZSANCHEZ J.F \& RAURET G., 2003. Prediction of trace element mobility in contaminated soils by sequential extraction. J. Environ. Qual., 32: 2054-2066.

SISSINO C.L.S. \& MOREIRA, J.C., 1996. Avaliação da contaminação e poluição ambiental na área de influência do aterro controlado do Morro do Céu, Niterói, Brasil. Cad. Saúde Pública, 12: 515-523. http://dx.doi.org/10.1590/S0102311X1996000400010

STENBERB B., 1999. Monitoring soil quality of arable land: microbiological indicator. Soil Plant. Sci., 49: 263-272. http:// dx.doi.org/10.1080/09064719950135669. 